\title{
Pengaruh Pembelajaran Matematika Menggunakan Model Learning Cycle Terhadap Hasil Belajar Siswa Pokok Bahasan Barisan Dan Deret Kelas XI IPA SMAN 1 Kerinci
}

\author{
Sapiah \\ SMAN 1 Kerinci \\ Correspondance email: sapiahbaharuddin31@gmail.com
}

\begin{abstract}
Abstrak. Tujuan dari penulisan penelitian ini adalah untuk mengetahui hasil belajar pembelajaran matematika pada materi pokok bahsaan barisan dan deret dengan menggunakan model pembelajaran learning cycle dengan sebelum menggunakan model pembelajara learning cycle (Model pembelajaran Ceramah). Penelitian ini menggunakan metode penelitian kuantitatif dengan pendekatan eksperimen. Populasi penelitian ini adalah seluruh siswa kelas XI IPA dengan menggunakan teknik purposive sampling, kelas yang akan dijadikan sampel dalam penelitian ini dilihat dari tingkat kemampuan yang dimilki masing-masing siswa dalam memahami materi pokok bahasan barisan dan deret, dimana sampelnya 25 orang siswa kelas control, dan 25 orang siswa kelas eksperimen. Teknik pengumpulan data yang dilakukan ada tiga tahap yaitu tahap persiapan, tahap pelaksanaan dan tahap akhir. Analisis uji instrument yang dilakukan pada penelitian eksperimen ini dengan menggunakan uji validitas dan reliabilitas tes, uji tingkat kesukaran soal tes, dan uji daya pembeda. Sedangkan teknik untuk menganalisis data dengan menggunakan uji normalitas, uji homogenitas, dan uji hipotesis dengan menggnakan t-test. Hasil penelitian ini menunjukan adanya perbedaan dalam hasil belajar siswa pada materi pokok bahasan barisan dan deret sebelum menggunakan model pembelajaran Learning Cycle dan setalah menggunakan model pembelajaran Learning Cycle. Hal ini dapat dilihat dengan menggunakan uji t test bagian $t$-test for Equality of Means diketahui nilai sig. (2 tailed) sebesar 0,000 <0,05.
\end{abstract}

Kata Kunci: Pembelajaran Matematika; Learning Cycle; Hasil Belajar

\begin{abstract}
The purpose of writing this research is to determine the learning outcomes of mathematics learning on the subject matter of the language of sequences and series by using the learning cycle learning model before using the learning cycle learning model (Lecture learning model). This study uses quantitative research methods with an experimental approach. The population of this research is all students of class XI IPA using purposive sampling technique, the class that will be sampled in this study is seen from the level of ability possessed by each student in understanding the subject matter of sequences and series, where the sample is 25 control class students, and 25 experimental class students. There are three stages of data collection techniques, namely the preparation stage, the implementation stage and the final stage. The analysis of the instrument test carried out in this experimental study used a test of validity and reliability, a test of the level of difficulty of the test items, and a test of discriminating power. While the technique to analyze the data using normality test, homogeneity test, and hypothesis testing using $t$-test. The results of this study indicate that there are differences in student learning outcomes on the subject matter of sequences and series before using the Learning Cycle learning model and after using the Learning Cycle learning model. This can be seen by using the t-test part of the t-test for Equality of Means, the sig value is known. (2 tailed) of $0.000<0.05$.
\end{abstract}

Keywords: Mathematics Learning; Learning Cycle; Learning Outcomes

\section{PENDAHULUAN}

Fenomena perubahan arus globalisasi secara tidak langsung berdampak pada dunia pendidikan yang tidak dapat terelakan lagi keberadaannya. Hal ini dapat dilihat dari pesatnya kemajuan ilmu pengetahuan dan teknologi yang merambah dalam segala aspek kehidupan manusia. Sehingga, menuntut adanya persaingan sumber daya manusia semakin ketat. Salah satu upaya yang dilakukan manusia untuk menghadapi persaingan di masa depan yaitu dengan menempuh jalur pendidikan. Pendidikan merupakan suatu proses perubahan sikap dan perilaku seseorang dari yang tidak baik menjadi baik, dari yang tidak tahu menjadi tahu serta dapat mendewasaan seseorang melalui proses pembelajaran dan pelatihan sehingga dapat membentuk karakter pribadi seseorang tersebut. Proses pembelajaran dan pelatihan sering dijumpai pada jenjang pendidikan formal. Pendidikan formal merupakan salah satu point penting dalam upaya membentuk sumber daya manusia yang berkualitas, karena melalui jenajang pendidikan formal memungkinkan untuk mengembangkan kemampuan akademis maupun keterampilan lain yang dimiliki peserta didik sebagai sumber daya masusia dimasa depan sehingga dapat digunakan secara efektif dan efisien untuk bekal kehidupannya.

Pendidikan formal terbagi menjadi 3 jenjang yaitu jenjang pendidikan dasar, pendidikan menengah dan juga pendidikan tinggi. Jenjang pendidikan dasar dimulai dari Sekolah Dasar (SD) pendidikan menengah dimulai dari Sekolah Menengah Pertama (SMP) dan Sekolah Menengah Atas (SMA), sedangkan pendidikan tinggi bisa berbentuk pendidikan di Universitas, Sekolah Tinggi, dan juga Akademi. Jenjang pendidikan menengah khususnya Sekolah Menengah Atas (SMA) 
Sapiah, Pengaruh Pembelajaran Matematika Menggunakan Model Learning Cycle Terhadap Hasil Belajar Siswa Pokok Bahasan Barisan Dan Deret Kelas XI IPA SMAN 1 Kerinci

merupakan salah satu jenjang pendidikan yang mempelajari kajian bidang ilmu dengan cakupan yang luas, serta pengelompokan mata pelajaran berdasarkan minat serta kemampuan akademis. Teruntuk siswa tingkat SMA telah terbentuk kepribadian yang mandiri dan dituntut untuk memlki pola pikir yang logis, karena pada saat siswa menyelesaikan jenjang pendidikan tersebut mereka akan dihadapkan pada kehidupan yang sebenarnya, memilih melanjutkan pendidikan ke ke jenjang pendidikan yang lebih tinggi atau memilih untuk memasuki dunia kerja. Pada dasarnya apaun keputusan yang dipilih akan mempengaruhi masa depannya, sehingga dengan memilki pola piker yang logis dapat dijadikan bekal bagi mereka untuk menikmati masa depan.

Di era globalisasi yang membantu suatu informasi cepat diterima di kalangan pelajar diperlukan penyaringan terlebih dahulu untuk informasi yang baik atau tidak serta memilah dan memilih kemungkinan dampak yang akan terjadi. Untuk itulah diperlukan suatu proses pembelajaran yang tepat, efektif dan efesien bagi siswa dengan menggunakan berbagai model pembelajaran yang berpusat pada siswa (student learning center), sehingga dapat memberikan hasil yang maksimal dan hasil yang dibutuhkan siswa dikemudian hari. Namun, dalam prakteknya proses pembelajaran hanya bertumpu pada guru yang aktif menjelaskan dengan menggunakan salah satu model pembelajaran konvensional seperti model pembelajaran ceramah. Karena sebagian besar guru beranggapan bahwa model pembelajaran konvensional ini sangat mudah diterapkan dalam proses pembelajaran. Dimana, dengan model pembelajaran konvensional guru berperan aktif dominan dalam menjelaskan suatu pokok bahasan materi dari suatu mata pelajaran dan siswa hanya menjadi pendengar apa yang telah disampaikan oleh guru. Hal inilah yang dapat menyebabkan kondisi dan situasi belajar menjadi tidak kondusif, karena siswa akan cepat merasa jenuh serta bosan dengan pembelajaran yang monoton tersebut, dan akhirnya tujuan dari pembelajaran tersebut tidak tersampaikan dengan baik.

Interaksi guru dan siswa dalam proses pembelajaran sangat menentukan berhasil atau tidaknya proses pembelajaran. Untuk mewujudkan keberhasilan dalam proses pembelajaran sebaiknya guru harus bisa menciptakan situasi belajar yang kondusif, serta menerapkan pembelajaran yang ideal dengan materi dengan kondisi yang ada disekitar pebelajar, agar siswa mudah mencerna dan menyerap apa yang telah dipelajari. Pembelajaran ideal yang dimaksudkan yaitu dimana siswa dituntut untuk lebih aktif dalam proses suatu proses pembelajaran, guru hanya sebagai fasilitator untuk memandu, mengawasi dan mengarahkan proses pembelajaran agar tetap sesuai dengan apa yang menjadi tujuan dari pembelajaran tersebut. Pembelajaran berpusat pada siswa tentu ada campur tangan guru dalam memikirkan model pembelajaran yang tepat untuk mengarahkan siswa menjadi student learning center. Guru juga harus memikirkan model pembelajaran yang digunakan dalam proses pembelajaran agar menarik minat dan antusias siswa dalam belajar. Salah satu model pembelajaran yang menjadikan pembelajaran student learning center yaitu dengan menggunakan model pembelajaran Siklus Belajar (Learning Cycle).

Learning Cycle merupakan rangkaian kegiatan yang diorganisasikan sedemikian rupa sesuai dengan apa yang dibutuhkan siswa sehingga siswa dapat mengetahui kompetensi-kompetensi yang harus dicapai dalam pembelajaran dengan cara siswa ikut serta berperan aktif dalam proses pembelajaran. Seperti yang dikemukan Fajaroh (2008), yang menyatakan bahwa Learning cycle adalah suatu model pembelajaran yang berpusat pada siswa berupa rangkaian kegiatan berdasarkan tahapantahapan (fase) yang diorganisasi sedemikian rupa sehingga siswa dapat menguasai kompetensi-kompetensi yang harus dicapai dalam pembelajaran dengan berperan aktif. Penerapan model pembelajaran learning cycle ini dapat memberikan suasana belajar yang menyenangkan pada siswa sehingga siswa temotivasi, bersemangan, dan ikut berpartisipasi dalam kegiatan proses pembelajaran. Hal ini akan menciptakan suasa pembelajaran yang aktif dan efisien karena pembelajaran tidak di dominasi oleh guru saja, melainkan lebih menekankan keterlibatan siswa secara langsung dalam proses pembelajaran.

Apabila proses pembelajaran berajalan secara efktif dan efisien tentu secara tidak langsung akan berdampak pada hasil belajar yang diperoleh siswa itu sendiri. Sejalan dengan apa yang dikemukakan Dimyati dan Mudjiono (2013) bahwa hasil belajar merupakan hasil dari sesuatu interaksi tindak belajar dan tindak mengajar. Tindak belajar dilihat dari sisi siwa itu sendiri dengan ditunjukanya hasil belajar sebagai berakhirnya pembelajaran dan puncak dari proses pembelajaran. Sedangkan tindak mengajar bisa dilihat dari sisi guru, dimana hasil akhir dari proses pembelajaran yang ditandai dengan evaluasi hasil belajar pada siswa.

Berdasarkan observasi selama melakukan proses pembelajaran di kelas XI IPA SMAN 1 Kerinci menunjukan bahwa siswa kurang aktif dan juga tidak bersemangat dalam mengikuti pembelajaran. Ha tersebut dapat dilihat dari masih minimnya jumlah siswa yang mau mengajukan suatu pertanyaan pada materi yang diajarkan maupun mengungkapkan gagasan mereka pada saat pembelajaran berlangsung. Masih banyaknya siswa yang mengalami kesulitan dalam memahami materi pembelajaran matematika pada pokok bahasan materi barisan dan deret. Hal ini dikarenakan masih seringnya guru mengajar dengan tidak menggunakan model pembelajaran konvensional dan monotonnya guru dalam mengajar mengakibtkan siswa juga kurang aktif pada saat proses pembelajaranyang sedang berlangsung. Sehingga kondisi tersebut membuat suasana belajar 
Sapiah, Pengaruh Pembelajaran Matematika Menggunakan Model Learning Cycle Terhadap Hasil Belajar Siswa Pokok Bahasan Barisan Dan Deret Kelas XI IPA SMAN 1 Kerinci

menjadi monoton dan membuat siswa merasa bosan dan tidak termotivasi untuk mengikuti proses pembelajaran. Oleh karena itu penulis memilih model pembelajaran learning cycle, dimana model pembelajaran ini berpusat pada siswa dan guru sebagai fasilitator yang mengelola berlangsungnya tahap-tahap dalam model pembelajaran tersebut. Menurut Sujarwo (2011) model pembelajaran learning cycle memakai pendekatan konstruktivis, sehingga pembelajaran menitik beratkan pada terbangunnya pemahaman sendiri oleh siswa secara aktif, kreatif, produktif berdasarkan pengetahuan dan pengalaman awal. Tahapan model pembelajaran learning cycle menuntun siswa untuk memahami konsep pembelajaran matematika pada pokok bahasan materi barisan dan deret melalui kegiatan penyelesaian masalah yang berkaitan ataupun dengan melakukan percobaan.

Mealui model pembelajaran learning cycle siswa akan termotivasi untuk belajar aktif dan memiliki gagasan-gagasan sehingga tercipta kreativitas. Pembelajaran matematika pada materi barisan dan deret dengan menggunakan model pembelajaran learning cycle dapat membantu siswa mengkonstruksikan pengetahuannya berdasarkan pengalaman, serta dapat mengembangkan keterampilan untuk berpikir kreatif. Keaktifan siswa dalam proses pembelajaran matematika pada pokok bahasan materi barisan dan deret akan mempengaruhi hasil belajar siswa tersebut. Dimana hasil belajar mewujudkan perubahan sikap dan kepribadian siswa untuk lebih berperstasi dalam berbagai aktivitas pembelajaran. Hasil belajar siswa merupakan suatu indikasi pencapaian tujuan pembelajaran yang sesuai dengan standar kompetensi dan kompetensi dasar yang harus dipenuhi pada materi pembelajaran barisan dan deret. Adapun tujuan dari penulisan ini adalah untuk mengetahui hasil belajar pembelajaran matematika pada materi pokok bahsaan barisan dan deret dengan menggunakan model pembelajaran learning cycle dengan sebelum menggunakan model pembelajara learning cycle.

\section{Landasan Teori}

\section{Pembelajaran Matematika}

Belajar bukan hanya sekedar untuk mengingat saja, tetapi kajianya lebih luas yakni mengalami sesuatu sebagai pengalaman dan pembelajaran. Sejalan dengan pendapat Arifin (2012) yang menyatakan bahwa pembelajaran merupakan suatu proses atau kegiatan yang sistematis bersifat interaktif dan komunikatif antara guru dengan siswa, sumber belajar, dan lingkungan untuk menciptakan suatu kondisi yang memungkinkan terjadinya tindakan belajar siswa. Definisi lain tentang pembelajaran yaitu suatu proses membelajarkan pembelajar yang disusun, direncanakan, dilaksanakan dan dievaluasi secara sistematis agar dapat menacapai tujuan pembelajaran yang efektif dan efisien (Komalasari, 2010).
Pembelajaran merupakan suatu sistem atau proses membelajarkan pembelajar yang direncanakan, dilaksanakan dan dievaluasi secara sistematis agar pembelajaran dapat mencapi tujuan pembelajaran secara efektif dan efisien" (Komalasari, 2010). Sedangkan Sanjaya (2011) mengemukakan bahwa pembelajaran merupakan suatu sistem yang kompleks yang keberhasilannya dapat dilihat dari dua aspek yaitu pertama aspek produk seperti keberhasilan siswa mengenai hasil yang diperoleh dengan mengabaikan proses pembelajaran dan kedua adalah aspek proses seperti keberhasilan siswa dilihat dari proses mengikuti pembelajaran samapai mencapai tujuan pembelajaran. Adapun tujuan pembelajaran yaitu suatu rumusan secara rinci tentang apa saja yang harus dikuasai atau dipahami siswa sebagai akibat dari hasil pembelajaran yang diimplementasikan dalam bentuk tingkah laku yang dapat diamati dan diukur (Cahyono, 2013).

Lebih lanjut dari definisi pembelajaran diatas, apabila dikaitkan dengan pembelajaran matematika para siswa dituntut untuk membiasakan dalam mendapatkan pemahaman melalui pengalaman tentang sifat-sifat yang dimiliki dan yang tidak dimiliki dari sekumpulan objek (abstraksi). Menurut Inayati (2012) dalam pembelajaran matematika siswa diberi pengalaman menggunakan matematika sebagai alat untuk memahami atau menyampaikan informasi misalnya melalui persamaanpersamaan, atau tabel-tabel dalam model-model matematika yang merupakan penyederhanaan dari soalsoal cerita atau soal-soal uraian matematika lainnya. Sedangkan menurut Rusyanti (2014) menyatakan bahwa pembelajaran matematika merupakan suatu proses interaksi antara guru dan siswa yang melibatkan pengembangan pola berfikir dan mengolah logika pada suatu lingkungan belajar yang sengaja diciptakan oleh guru dengan berbagai metode agar program belajar matematika tumbuh dan berkembang secara optimal dan siswa dapat melakukan kegiatan belajar secara efektif dan efisien.

Pembelajaran matematika bagi para siswa merupakan pembentukan pola pikir dalam pemahaman suatu pengertian maupun dalam penalaran suatu hubungan diantara pengertian-pengertian itu. NCTM (National Coucil of Teachers of Mathematics) dalam Suherman (2003) mengusulkan 4 (empat) prinsip pembelajaran matematika, yaitu: 1) Matematika sebagai pemecahan masalah; 2) Matematika sebagai penalaran; 3) Matematika sebagai komunikasi; dan 4) Matematika sebagai suatu hubungan. Masih menurut Suherman (2003) Tujuan umum dari pembelajaran matematika yaitu pertama, pembelajaran matematika pada jenjang pendidikan dasar dan menengah adalah memberikan penekanan pada penataan latar dan pembentukan sikap siswa. Kedua memberikan penekanan pada keterampilan dalam penerapan matematika, baik dalam kehidupan sehari-hari maupun dalam membantu mempelajari ilmu 
Sapiah, Pengaruh Pembelajaran Matematika Menggunakan Model Learning Cycle Terhadap Hasil Belajar Siswa Pokok Bahasan Barisan Dan Deret Kelas XI IPA SMAN 1 Kerinci

pengetahuan lainnya. Adapun fungsi mata pelajaran matematika adalah sebagai alat, pola pikir, dan ilmu atau pengetahuan (Suherman, 2003). Dalam pembelajaran matematika guru hanya dijadikan sebagai motivator dan sebagai pembmbing siswa dalam mengikuti proses pembelajaran matematika di sekolah.

\section{Model Learning Cycle}

Model pembelajaran secara umum dapat didefinisikan sebagai suatu perencanaan atau pedoman yang digunakan dalam proses pembelajaran di kelas untuk mencapai kompetensi/tujuan pembelajaran yang diharapkan. Model pembelajaran juga dapat didefinisikan sebagai suatu kerangka konseptual yang mendeskripsikan prosedur sistematis dalam mengorganisasikan pengalaman belajar siswa untuk mencapai tujuan berlajar tertentu dan berfungsi sebagai pedoman dalam merancanakan dan melaksanakan aktivitas belajar mengajar (Syaiful, 2010). Lebih lanjut Rusman (2014), menyatakan bahwa definisi model pembelajaran itu sebagai suatu rencana atau pola yang dapat digunakan untuk membentuk kurikulum (rencana pembelajaran jangka panjang), merancang bahan-bahan pembelajaran, dan membimbing pembelajaran di kelas atau yang lainnya. Senada dengan itu, Isjoni (2013) berpendapat bahwa definisi model pembelajaran adalah suatu pola atau rencana yang sudah direncanakan sedemikian rupa dan digunakan untuk menyusun kurikulum, mengatur materi pelajaran, dan memberi petunjuk kepada pengajar di kelasnya.

Suatu rancangan atau pola yang digunakan sebagai pedoman pembelajaran di kelas disebut dengan model pembelajarn (Ngalimun, 2012). Model pembelajaran memilki berbagai jenis seperti yang diungkapkan Zaini (2010) sebagai berikut:

1. Model Pembelajaran Aktif yaitu suatu pembelajaran yang mengajak siswa untuk belajar secara aktif. Siswa secaraa aktif menggunakan otak mereka baik untuk menemukan ide pokok dari materi pelajaran, memecahkan persoalan atau mengaplikasikan pengetahuan apa saja yang dimilikinya.

2. Model pembelajaran Konvensional yaitu model pembelajaran yang hanya berpusat pada informasi yang disampaikan guru.

Berdasarkan jenis-jenis model pembelajaran diatas, learning cycle termasuk jenis model pembelajaran aktif dimana pembelajaranya leih menuntut siswa lebih aktif dalam pembelajaran. Dengan memilih model pembelajaran yang tepat akan menciptakan suasana belajar yang kondusif sehingga siswa termotivasi dalam belajar. memilih dan menggunakan model pembelajaran yang tepat juga merupakan salah satu unsur penentu keberhasilan atau kesuksesan dalam kegiatan belajar.

Adapun definisi model pembelajaran Learning Cycle merupakan suatu model pembelajaran yang pada implementasinya akan berpusat pada siswa dan tidak didominasi oleh guru pada saat proses pembelajaran berlangsung. Hal ini bertujuan agar siswa dapat aktif sehingga meningkatkan kemampuan yang ada pada diri siswa itu sendiri. Learning cycle merupakan suatu model pembelajaran yang berpusat pada siswa, dimana model pembelajaran ini memilki rangkaian tahap-tahap kegiatan atau fase yang diorganisasi sedemikian rupa sehingga siswa dapat menguasai kompetensi-kompetensi yang harus dicapai dalam pembelajaran dengan berperan aktif (Fajaroh, 2008). Lebih lanjut Rapi (2011) menyatakan bahwa model pembelajaran Learning Cycle dapat meningkatkan perilaku alamiah siswa karena model pembelajaran ini memberikan peluang kepada siswa untuk mengkontruksi pengetahuan yang dimiliki serta mengaitkan konsep-konsep yang sudah dipahami dengan konsep-konsep yang akan dipelajari sehingga pembelajaran menjadi lebih bermakna.

Khairani (2011) berpendapat bahwa model pembelajaran learning cycle memiliki fase-fase yang yang menuntut siswa untuk lebih aktif mengeksplorasi dan memperkaya pemahaman siswa terhadap konsepkonsep yang dipelajari sehingga dapat membuat hasil belajar siswa menjadi meningkat. Fase-fase tersebut terdiri dari $5 \mathrm{E}$ diantaranya (engagement) atau melibatkan, (exploration) atau menyelidiki, (explanation) atau penjelasan, (elaboration) atau menguraikan, dan (evaluation) atau menilai. Hal yang sama juga diungkapkan oleh Trianto (2011) bahwa model pembelajaran Learning Cycle memiliki tahapan tahapan diantaranya Eksplorasi (exploration), Pengenalan konsep (concept introduction), Penerapan konsep (concept application), Perluasan (elaboration/extention), dan Evaluasi (evaluation). Sedangkan menurut Windiarti (2014) model pembelajaran learning cycle memilki fase-fase yang harus dikuasai siswa yakni 7E diantaranya 1) Elicit (mendatangkan pangetahuan awal siswa); 2) Engage (ide, rencana pembelajaran dan pengalaman); 3) Eksplore (menyelidiki); 4) Explain (menjelaskan), 5) Elaborate (menerapkan); 6) Evaluate (menilai), dan 7) Extend (memperluas).

Model pembelajaran learning cycle mempunyai kelebihan dan kekurangan dalam pelaksanaanya seperti yang dikemukakan Fajaroh (2008), dimana kelebihan dari model pembelajaran tersebut yakni 1) Memberikan motivasi kepeda siswa untuk lebih aktif dalam pembelajaran dan menambah rasa keingintahuan; 2) Melatih siswa belajar menemukan konsep melalui kegiatan eksperimen; 3) Melatih siswa untuk menyampaikan secara lisan konsep yang telah mereka pelajari; 4) Memberi kesempatan kepada siswa untuk berpikir, mencari, menemukan dan menjelaskan contoh penerapan konsep yang telah dipelajari. Sedangkan kekurangan dari model pembelajaran learning cycle ini diantaranya yaitu 1) Efektifitas pembelajaran rendah jika 
guru kurang menguasai materi dan langkah-langkah pembelajaran; 2) Menuntut kesungguhan dan kreativitas guru dalam merancang dan melaksanakan proses pembelajaran; 3) Memerlukan pengelolaan kelas yang lebih terencana dan terorganisasi; dan 4) Memerlukan waktu dan tenaga yang lebih banyak dalam menyusun rencana dan melaksanakan pembelajaran.

\section{Hasil Belajar}

Hasil belajar berawal dari bahasa Belanda yang dikenal dengan istilah prestatie, apabila diserap dalam Bahasa Indonesia menjadi prestasi yang memiliki arti hasil dari usaha. Hasil belajar biasanya berkaitan dengan kegiatan belajar, karena kegiatan belajar sebagai proses sedangkan hasil belajar sebagi hasil yang dicapai seseorang setelah mengalami proses belajar terlebih dahulu dengan mengadakan suatu evaluasi dari proses belajar yang telah dilakukan. Dengan kata lain hasil belajar merupakan kemampuan-kemampuan yang dipunyai siswa setelah melakukan pengalaman belajar yang mencerminkan tujuan pada tingkat tertentu akan keberhasilan pencapaian siswa yang dinyatakan dengan nilai tes atau angka/huruf (Sudjana, 2010).

Menurut Sukmadinata (2009) mendefinisikan hasil belajar atau achievement yaitu sebagai realisasi atau pengembanagan dari kecekapan-kecekapan potensial atau kapasitas yang dimiliki seseorang, dalam hal ini adalah siswa. Penguasaan hasil belajar yang dimilki siswa dapat dilihat dari perilakunya, baik perilaku dalam bentuk penguasaan pengetahuan, keterampilan berfikir maupun ketrampilan motorik. Lebih lanjut Jihad dan Haris (2010) mendefinisikan hasil belajar sebagai suatu perubahan tingkah laku siswa secara nyata setelah dilakukan proses belajar mengajar yang sesuai dengan tujuan pengajaran. Sedangkan Supardi (2015) berpendapat Keberhasilan belajar adalah tahap pencapaian aktual yang ditunjukan dalam bentuk perilaku yang meliputi aspek kognitif, aspek afektif maupun aspek psikomotor serta dapat diperlihatkan dalam bentuk kebiasaan, sikap, dan penghargaan.

Perwujudan dari bentuk pola-pola perbuatan, nilainilai, pengertian-pengertian, sikap-sikap, apresiasi dan ketrampilan disebut sebbagai hasil belajar (Suprijono, 2012). Setiap pendidik atau guru tentunya mempunyai keinginan agar dapat meningkatkan hasil belajar siswa yang diajarnya. Oleh karena itu pendidik atau guru hendaknya harus mempunyai hubungan yang kooperatif dengan siswa dalam proses pembelajaran. Setiap proses pembelajaran keberhasilannya diukur dari seberapa jauh hasil belajar yang dicapai siswa melalui suatu tes evaluasi. Menurut Bloom dalam Sudjana (2016) membagi hasil belajar ke dalam 3 ranah yaitu 1) ranah kognitif berkenaan dengan hasil belajar intelektual yang terdiri dari enam aspek, yaitu pengetahuan, pemahaman, aplikasi, analisis, sintesis dan evaluasi ; 2) ranah afektif berkenaan dengan sikap yang terdiri dari lima aspek yaitu penerimaan, jawaban, penilaian, organisasi, dan internalisasi; dan 3) ranah psikomotorik berkenaan dengan hasil belajar ketrampilan dan kemampuan bertindak yang terdiri dari enam aspek diantaranya gerakan reflek, ketrampilan gerakan dasar, ketrampilan perseptual, keharmonisan atau ketepatan, gerakan ketrampilan komplek, gerak ekspresif dan interprektif.

\section{METODE}

Dari permasalahan yang telah dipaparkan pada latar belakang masalah, penelitian ini menggunakan metode penelitian kuantitatif dengan pendekatan eksperimen. Penelitian eksperimen adalah metode penelitian yang dapat mencari pengaruh perlakuan tertentu terhadap yang lain dalam kondisi yang terkendalikan (Sugiyono, 2017). Penelitian ini dilakukan di SMAN 1 Kerinci dengan populasinya siswa kelas XI IPA 1, kelas XI IPA 2, dan kelas XI IPA 3 yang total kaeseluruhanya berjumlah 75 orang. Pengambilan sampel pada penelitian ini menggunakan teknik purposive sampling, dimana teknik sampling ini mempertimbangkan jenis penelitian yang digunakan dimana penelitian ini membutuhkan kelas kontrol dan kelas eksperimen. (Sugiyono, 2017). Kelas yang akan dijadikan sampel dalam penelitian ini dilihat dari tingkat kemampuan yang dimilki masing-masing siswa dalam memahami materi pokok bahasan barisan dan deret.

Adapun yang dijadikan sampel dalam penelitian eksperimen ini adalah sebagai berikut:

Tabel 1. Sampel Penelitian

\begin{tabular}{ccc}
\hline Kelas & Jumlah Siswa & Keterangan \\
\hline XI IPA I & 25 & Kelas Kontrol \\
XI IPA II & 25 & Kelas Eksperimen \\
Total & 50 & \\
\hline
\end{tabular}

Sumber: SMAN 1 Kerinci 2020

Pada desain penelitian eksperimen ini baik kelompok eksperimen maupun kelompok kontrol tidak dilakukan pemilihan secara random, hal tersebut bisa dilihat pada tabel sebagai berikut:

Tabel 2. Rancangan Penelitian Yang Dilakukan

\begin{tabular}{ccc}
\hline Learning Cycle (A1) & $\begin{array}{c}\text { Materi Barisan } \\
\text { dan Deret }\end{array}$ & $\begin{array}{c}\text { Model } \\
\text { Ceramah (A2) }\end{array}$ \\
\hline Tingsil Belajar & A1B1 & A2B1 \\
Sedang (B2) & A1B2 & A2B2 \\
Rendah (B3) & A1B3 & A2B3 \\
\hline
\end{tabular}

Interpretasi dari tabel tersebut dapat dijelaskan sebagai berikut:

A1B1 : Kelompok yang mengikuti pembelajaran menggunakan model pembelajaran Lerning Cycle memilki hasil belajar tinggi

A1B2 : Kelompok yang mengikuti pembelajaran menggunakan model pembelajaran Lerning Cycle memilki hasil belajar sedang 
A1B3 : Kelompok yang mengikuti pembelajaran menggunakan model pembelajaran Lerning Cycle memilki hasil belajar rendah

A2B1 : Kelompok yang mengikuti pembelajaran menggunakan model pembelajaran ceramah memilki hasil belajar tinggi

A2B2 : Kelompok yang mengikuti pembelajaran menggunakan model pembelajaran ceramah memilki hasil belajar sedang

A2B3 : Kelompok yang mengikuti pembelajaran menggunakan model pembelajaran ceramah memilki hasil belajar rendah

Adapun teknik pengumpulan data yang dilakukan dalam penelitian eksperimen ini diantaranya 1) Tahap Persiapan meliputi: a) Mengambil data jumlah siswa kelas XI IPA SMAN 1 Kerinci tahun ajaran 2020/2021; b) Menentukan kelompok sampel yang akan diteliti yang terdiri dari kelas eksperimen dan kelas control; c) Melakukan tes kemampuan awal pada kelas XI IPA SMAN 1 Kerinci ; d) Menetapkan materi yang akan diajarkan untuk kepentingan penelitian; dan e) Menyusun rencana pembelajaran yang disusun dengan berpedoman pada kurikulum mata pelajaran matematika SMA terbaru. 2) Tahap Pelaksanaan meliputi proses pembelajaran siswa pada kelas eksperimen menggunakan model pembelajaran Learning Cycle, sedangkan pada kelas kontrol proses pembelajaran menggunakan model pembelajaran ceramah sesuai dengan langkah-langkah yang telah diuraikan pada tinjauan pustaka. 3) Tahap Akhir meliput; a) Mempersiapkan soal post-test; b) Memberikan soal posttest pada siswa kelas eksperimen maupun kelas kontrol diakhir pokok pembahasan; c) Menganalis nilai hasil post-test dan menarik kesimpulan dari analisis tersebut. Tindakan perlakuan yang dilakukan pada penelitian eksperimen ini secara singkat dapat diuraikan sebagai berikut:

Tabel 3. Tindakan Perlakuan

\begin{tabular}{llll}
\hline \multicolumn{1}{c}{ Kelompok } & Pretes & Perlakuan & Post Tes \\
\hline Kelompok Eksperimen & $\mathrm{T}_{0}$ & $\mathrm{M}_{1}$ & $\mathrm{~T}_{1}$ \\
Kelompok Kontrol & $\mathrm{T}_{0}$ & $\mathrm{M}_{2}$ & $\mathrm{~T}_{1}$ \\
\hline
\end{tabular}

Keterangan

$\mathrm{M}_{1} \quad$ : Pembelajaran dengan menggunakan Model Learning Cycle Pada Mata Pelajaran Matematika Pokok Bahasan Materi Barisan dan Deret

$\mathrm{M}_{2} \quad$ : Pembelajaran dengan menggunakan Model Ceramah Pada Mata Pelajaran Matematika Pokok Bahasan Materi Barisan dan Deret

$\mathrm{T}_{0} \quad$ : Tes Kemampuan Awal

$\mathrm{T}_{1} \quad$ : Tes Kemampuan Akhir

Analisis uji instrument yang dilakukan pada penelitian eksperimen ini dengan menggunakan uji validitas dan reliabilitas tes yang akan diberikan dengan bantuan program SPSS for Windows versi 25 yang berpedoman pada panduan yang dikemukakan oleh Ghozali (2018). Langkah selanjutnya melakukan uji tingkat kesukaran butir item tes dengan menggunakan rumus yang dikemukakan Suprijono (2012), dan kriteria yang dikemukakan adalah $0,0 \leq \mathrm{P}<0,30$ (Sukar); $0,30 \leq$ $\mathrm{P}<0,70$ (Sedang); dan $0,70 \leq \mathrm{P}<1,00$ (Mudah). Langkah terakhir melakukan uji daya pembeda suatu soal tes yang menurut Arikunto (2013) menyatakan bahwa uji daya pembeda suatu soal menyatakan seberapa jauh kemampuan butir soal tersebut mampu membedakan antara siswa yang dapat menjawab soal dengan siswa yang tidak dapat menjawab soal dengan kriteria berikut: $0,0 \leq \mathrm{P}<0.20$ (Jelek); $0,20 \leq \mathrm{P}<0,40$ (Cukup); 0,40 $\leq \mathrm{P}<0,70$ (Baik); dan 0,70 $\leq \mathrm{P}<1,00$ (Sangat baik). Setelah melakukan analisis uji instrument, maka langkah selanjutnya adalah teknik untuk menganalisis data dengan menggunakan uji normalitas, uji homogenitas, dan uji hipotesis dengan menggnakan ttest.

\section{HASIL DAN PEMBAHASAN}

Analisis uji instrument yang telah dilakukan dengan menggunakan uji validitas untuk mengetahui ukuran tingkat kevalidan atau kesahihan dari instrument tes yang diujicobakan dengan 10 butir item soal dapat dilihat pada tabel berikut:

Tabel 4. Validitas Instrumen Tes

\begin{tabular}{lcccc}
\hline No & $\begin{array}{c}\text { Butir } \\
\text { Pertanyaan }\end{array}$ & $\begin{array}{c}\text { Corrected } \\
\text { Item Total } \\
\text { Correlation }\end{array}$ & $\mathbf{R}_{\text {Tabel }}$ & Keterangan \\
\hline 1. & Butir1 & 0,517 & 0,323 & Valid \\
2. & Butir2 & 0,604 & 0,323 & Valid \\
3. & Butir3 & 0,656 & 0,323 & Valid \\
4. & Butir4 & 0,473 & 0,323 & Valid \\
5. & Butir5 & 0,545 & 0,323 & Valid \\
6. & Butir6 & 0,718 & 0,323 & Valid \\
7. & Butir7 & 0,586 & 0,323 & Valid \\
8. & Butir8 & 0,739 & 0,323 & Valid \\
9. & Butir9 & 0,659 & 0,323 & Valid \\
10. & Butir10 & 0,545 & 0,323 & Valid \\
\hline
\end{tabular}

Butir pertanyaan yang berjumlah 10 soal di ujikan kepada 25 orang siswa kelas XI IPA SMAN 1 Kerinci, dimana $\mathrm{r}$ tabel menjadi 0,323 sedangkan $\mathrm{r}$ hitung > 0,323 , sehingga dapat dikatakan butir pertanyaan tersebut dinyatakan valid. Analisis uji instrument selanjutnya adalah melakukan uji reliabilitas dengan hasil sebagai berikut:

Tabel 5. Reliabilitas Instrumen Tes Reliability Statistics

\begin{tabular}{|r|r|r|}
\hline $\begin{array}{c}\text { Cronbach's } \\
\text { Alpha }\end{array}$ & $\begin{array}{c}\text { Cronbach's Alpha Based } \\
\text { on Standardized Items }\end{array}$ & N of Items \\
\hline .865 & .838 & 10 \\
\hline
\end{tabular}


Hasil uji reliabilitas diketahui dari nilai Cronbach's Alpha Based on Standardized Items pada tabel 10 di atas sebesar $0,838>\mathrm{r}$ tabel sebesar 0,323. Hal ini menunjukan bahwa data tersebut dikatakan reliable dan dapat dilanjutkan penelitianya. Dari 10 item pertanyaan yang diajukan dapat menunjukan hasil belajar siswa untuk materi barisan dan deret. Bermutu atau tidaknya butir-butir item tes hasil belajar dapat diketahui dari derajat kesukaran atau taraf kesulitan yang dimiliki oleh masing-masing butir item tersebut. Adapun tingkat kesukaran masing-masing soal dapat digambarkan pada tabel, sebagai berikut:

Tabel 6. Kriteria Tingkat Kesukaran Instrumen Penelitian

\begin{tabular}{cccc}
\hline $\begin{array}{c}\text { No. } \\
\text { Butir }\end{array}$ & $\begin{array}{c}\text { Banyak siswa } \\
\text { Menjawab Benar }\end{array}$ & $\begin{array}{c}\text { Tingkat } \\
\text { Kesukaran }(\%)\end{array}$ & Tafsiran \\
\hline 1 & 10 & 0,40 & Sedang \\
2 & 8 & 0,32 & Sedang \\
3 & 15 & 0,60 & Sedang \\
4 & 14 & 0,56 & Sedang \\
5 & 7 & 0,28 & Sukar \\
6 & 12 & 0,48 & Sedang \\
7 & 10 & 0,40 & Sedang \\
8 & 11 & 0,44 & Sedang \\
9 & 13 & 0,52 & Sedang \\
10 & 9 & 0,36 & Sedang \\
\hline
\end{tabular}

Telah diketahui bahwa tingkat kesukaran soal yang tertera pada tabel 6 di atas, sebaran masing-masing butir item soal materi barisan dan deret hanya satu soal yakni soal no 5 yang tergolong sulit sedangkan nomor lainya seperti $1,2,3,4,6,7,8,9$, dan 10 tergolong sedang. Selanjutnya dilakukan uji daya pembeda soal untuk mengetahui kemampuan butir soal materi barisan dan deret mampu membedakan antara siswa yang bisa menjawab soal dengan benar dengan siswa yang tidak bisa menjawab soal pertanyaa. Adapun hasil uji daya pembeda dapat dilihat pada tabel berikut:

Tabel 7. Uji Daya Pembeda Instrumen Penelitian

\begin{tabular}{ccccc}
\hline $\begin{array}{c}\text { No. } \\
\text { Butir }\end{array}$ & $\begin{array}{c}\text { Kelompok } \\
\text { Atas }\end{array}$ & $\begin{array}{c}\text { Kelompok } \\
\text { Bawah }\end{array}$ & Beda & Indeks DP \\
\hline 1 & 8 & 5 & 3 & 0,30 \\
2 & 7 & 3 & 4 & 0,40 \\
3 & 6 & 3 & 3 & 0,30 \\
4 & 9 & 4 & 5 & 0,50 \\
5 & 6 & 5 & 1 & 0,10 \\
6 & 11 & 5 & 6 & 0,60 \\
7 & 8 & 4 & 4 & 0,40 \\
8 & 10 & 5 & 5 & 0,50 \\
9 & 10 & 4 & 6 & 0,60 \\
10 & 9 & 4 & 3 & 0,30 \\
\hline
\end{tabular}

Sebaran masing-masing butir item soal materi barisan dan deret yang terlhat hasilnya pada tabel $7 \mathrm{di}$ atas bahwa untuk tingkat daya pembedanya hanya satu soal yakni soal no 5 yang tergolong tingkat daya pembedanya jelek sedangkan nomor lainya seperti 1,2 , $3,4,6,7,8,9$, dan 10 tergolong sedang dalam tingkat daya pembeda soalnya. Setelah dilakukan uji analisis instrument terssebut, maka langkah selanjutnya melakukan uji analisis data dengan melakukan uji normalitas yang dilihat dari nilai chi square nya, dimana hasil uji normalitas tersebut dapat dilahat pada tabel berikut:

Tabel 8. Uji Normalitaas

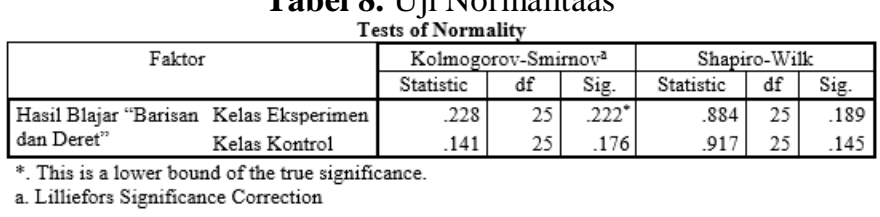

Dari hasil perhitungan uji normalitas di atas, dapat diketahui bahwa data kelas eksperimen dan kelas control dikatakan normal karena masing-masing nilai sig. Kolmogorov-Smirnov $^{\mathrm{a}}>0,05$ yakni untuk kelas eksperimen nilai sig. sebesar $0,222>0,05$ dan kelas control nilai sig. sebesar $0,176>0,05$. Untuk perhitungan selanjutnya adalah menghitung uji homogenitas dengan hasil sebagai berikut:

Tabel 9. Uji Homogenitas Test of Homogeneity of Variance

\begin{tabular}{|ll|r|r|r|c|}
\hline \multicolumn{1}{l}{ Test of Homogeneity of Variance } \\
\hline Hasil Belajar Siswa & Levene Statistic & df1 & \multicolumn{1}{|c|}{ df2 } & Sig. \\
& Based on Mean & 3.268 & 1 & 48 & .077 \\
& Based on Median & 3.203 & 1 & 48 & .080 \\
& Based on Median and with adjusted df & 3.203 & 1 & 40.327 & .081 \\
& Based on trimmed mean & 3.031 & 1 & 48 & .088 \\
\hline
\end{tabular}

Dari tabel 9 diatas, dapat diketahui bahwa uji homogenitas yang dilihat dari nilai sig. Based on Mean sebesar 0,077 yang lebih besar dari tarf signifikansi 0,05. Hal ini menandakan bahwa varian data yang dihasilkan adalah homogeny. Langkah terakhir adalah melakukan uji $\mathrm{t}$ test untuk menganalisis hipotesis penelitian ini yakni:

Ho : Tidak terdapat perbedaan hasil belajar siswa pada materi barisan dan deret dengan menggunakan model pembelajaran learning cycle dengan sebelum menggunakan model pembelajara learning cycle (Model pembelajaran Ceramah)

Ha : Terdapat perbedaan hasil belajar siswa pada materi barisan dan deret dengan menggunakan model pembelajaran learning cycle dengan sebelum menggunakan model pembelajaran learning cycle (Model pembelajaran Ceramah)

Adapun hasil dari perhitungan uji t tes untuk membuktikan hipotesa dalam penelitian ini dapat dilihat pada tabel berikut ini

Tabel 10. Uji t test

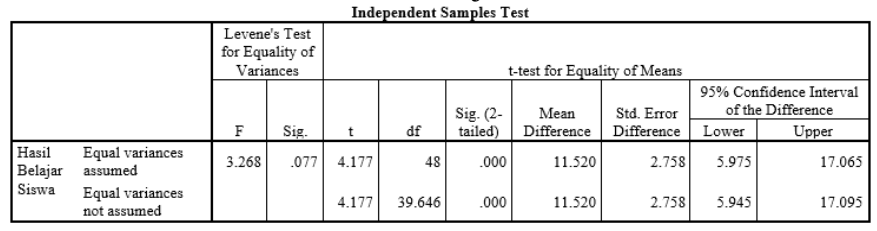


Sapiah, Pengaruh Pembelajaran Matematika Menggunakan Model Learning Cycle Terhadap Hasil Belajar Siswa Pokok Bahasan Barisan Dan Deret Kelas XI IPA SMAN 1 Kerinci

Dari hasil output $\mathrm{t}$ test $\mathrm{di}$ atas dengan menggunakan independent sample $t$ test dapat dilihat bagian t-test for Equality of Means diketahui nilai sig. (2 tailed) sebesar 0,000 $<0,05$. Maka sebagaimana dasar dalam pengambilan suatu keputusan hipotesa penelitian dalam uji independent sample t test dapat disimpulkan bahwa Ho ditolak dan Ha diterima. Dengan demikian dapat disimpulkan bahwa Terdapat perbedaan hasil belajar siswa pada materi barisan dan deret dengan menggunakan model pembelajaran learning cycle dengan sebelum menggunakan model pembelajaran learning cycle (Model pembelajaran Ceramah).

Berdasarkan hasil penelitian yang telah diperoleh, maka dalam model pembelajaran tipe Learning Cycle siswa lebih bersemangat dan lebih aktif dalam proses pembelajaran, serta dalam model pembelajaran ini tidak didominasi oleh guru dalam proses pembelajaranya. Dengan demikian, penerapan model pembelajaran Learning Cycle dalam pembelajaran matematika pada materi pokok bahasan barisan dan deret banyak memberikan manfaat baik kepada siswa maupun kepada penulis. Penelitian ini senada hasilnya dengan penelitian yang dilakukan Rahmayani (2017), dimana dalam penelitianya ditemukan bahwa menerapkan model pembelajaran Learning Cycle terbukti dapat meningkatkan hasl belajar siswa. Karena di setiap tahap kegiatan yang ada di dalam model pembelajaran Learning Cycle melibatkan siswa secara aktif, siswa tidak dipaksa untuk berpikir secara kompleks namun diarahkan untuk berpikir dari tahap mudah ke tahap yang lebih kompleks atau sulit. Dengan kata lain model pembelajaran konvensional (model pembelajaran ceramah) masih memilki beberapa kealemahan dalam pelaksanaanya, khususnya kendala yang dialami siswa dalam hal penelimaan umpan balik. Hal tersebut mengakibatkan model pembelajaran ceramah tidak bisa meningkatkan hasil belajar siswa karena siswa merasa bosan dan jenuh dalam belajar serta akan memerlukan waktu yang lama bagi guru untuk menjelaskan materi pelajaran. Artinya, hasil belajar siswa pada materi pokok bahasan barisan dan deret yang diajarkan dengan menggunakan model pembelajaran Learning Cycle lebih baik dibandingkan dengan hasil belajar siswa pada materi pokok bahasan barisan dan deret yang diajarkan dengan menggunakan model pembelajaran Ceramah. Secara keseluruhan dapat dijelaskan bahwa model pembelajaran Learning Cycle dapat memberikan motivasi belajar pada siswa dan variasi belajar, sehingga membuat siswa lebih focus dalam proses pembelajaran dan mencapai hasil belajar yang diharapkan.

\section{SIMPULAN}

Penelitian yang telah dilakukan ini, dapat ditarik suatu kesimpulan bahwa pada awalnya hasil belajar siswa pada mata pelajaran matematika dengan materi pokok bahasan barisan dan deret pada kelas XI IPA
SMAN 1 Kerinci belum dapat dikatakan baik, hal ini terbukti pada saat diskusi siswa masih banyak yang enggan bertanya, dan enggan untuk mengungkapkan pendapatnya. Setalah dilakukan penggunaan pembelajaran dengan model pembelajaran yang berebda maka dapat diperoleh adanya perbedaan dalam hasil belajar siswa pada materi pokok bahasan barisan dan deret sebelum menggunakan model pembelajaran Learning Cycle dan setalah menggunakan model pembelajaran Learning Cycle. Hal ini dapat dilihat dengan menggunakan uji t test bagian t-test for Equality of Means diketahui nilai sig. (2 tailed) sebesar 0,000 < 0,05 . Maka sebagaimana dasar dalam pengambilan suatu keputusan hipotesa penelitian dalam uji independent sample $t$ tes, sehingga pada saat belum menggunakan model pembelajaran Learning Cycle siswa mendapatkan hasil belajar yang jauh dari KKM dan setelah menggunakan model pembelajaran Learning Cycle jumlah siswa hasil belajarnya meningkat melebihi standar KKM yang ditargetkan.

\section{DAFTAR PUSTAKA}

Arikunto, Suhrsimi. 2013. Prosedur Penelitian Suatu Pendekatan Praktik. Jakarta: Rineka Cipta

Arifin, Zainal. 2012. Evaluasi Pembelajaran. Bandung: PT. Remaja Rosdakarya.

Cahyono N, Agus. 2013. Panduan Aplikasi Teori-Teori Belajar Mengajar. Yogyakarta: Diva Press.

Dimyati dan Mudjiono. 2013. Belajar Dan Pembelajaran. Jakarta: Rineka Cipta

Fajaroh, Dasna. 2008. Model Pembelajaran Inovatif: Pembelajaran Dengan Model Siklus Belajar (Learning Cycle). UM PRESS. Malang.

Ghozali, Imam. 2018. Aplikasi Analisis Multivariate dengan Program IBM SPSS 25. Semarang: Badan Penerbit Universitas Diponegoro

Inayati, Neneng. 2012. Upaya Meningkatkan Hasil Belajar Matematika Melalui Metode Kooperatif Tipe Team Games Tournament Pokok Bahasan Perkalian Dan Pembagian Bilangan Pada Siswa Kelas 2 SD Negeri Sidorejolor 01 Salatiga Semester II Tahun 2011/2012. Salatiga.

Isjoni. 2013. Pembelajaran Kooperatif. Yogyakarta: Pustaka Belajar.

Jihad, Asep dan Haris, Abdul. 2010. Evaluasi Pembelajaran. Yogyakarta: Multi Press

Khairani, Laila. 2011. Faktor-Faktor Yang Mempengaruhi Keberhasilan Belajar. Bandung: PT Remaja Rosdakarya.

Komalasari, Kokom. 2010. Pembelajaran Kontekstual: Konsep dan Aplikasi. Bandung: Refika Aditama.

Ngalimun. 2012. Strategi dan Model Pembelajaran. Banjarmasin: Aswaja Pressindo

Rahmayani, 2017. Pengembangan Perangkat Pembelajaran IPA Menggunakan Learning Cycle 
$7 E$ Untuk Meningkatkan Kemampuan Berpikir Kritis Siswa. Jurnal, 5(2), 957-965

Rapi, NK. 2011. Penerapan Model Siklus Belajar Empiris-Induktif (SBE) Dengan Peta Konsep Dalam Pembelajaran IPA Sebagai Upaya Meningkatkan Kualitas Hasil Belajar Siswa Kelas VIII SLTPN 3 Singaraja.

Rusman. 2014. Model-Model Pembelajaran (Mengembangkan Profesionalisme Guru). Jakarta: Raja Grafindo Persada.

Rusyanti, Hetty. 2014. Pengertian Pembelajaran Matematika. online. (http://www.kajianteori.com/2014/02/pengertianpembelajaranmatematika.html), diakses pada 21 April 2016.

Sanjaya, W. 2011. Strategi Pembelajaran. Jakarta: Kencana Prenada Media Group.

Sudjana, Nana. 2010. Dasar-dasar Proses Belajar. Bandung: Sinar Baru

Sudjana, Nana. 2016. Penilaian Hasil Proses Belajar Mengajar. Bandung: PT REMAJA ROSDAKARYA.

Sugiyono. 2017. Metode Penelitian Pendidikan Pendekatan Kuantitatif, Kualitatif, dan $R \& D$. Bandung: Alfabeta.

Suherman, Erman. 2003. Evaluasi Pembelajaran Matematika. Bandung: JICA UPI

Sujarwo. 2011. Model-model Pembelajaran Suatu Strategi Mengajar. Yogyakarta: Venus Gold Press

Sukmadinata, Nana Syaodih. 2009. Landasan Psikologi Proses Pendidikan. Bandung: PT Remaja Rosdakarya. hal 102-103

Supardi. 2015. Penilaian Autentik Pembelajaran Afektif, Kognitif, Psikomotor. Jakarta: PT Raja Grafindo Persada.

Suprijono, Agus. 2012. Cooperative Learning: Teori dan Aplikasi Paikem. Yogyakrta: Pustaka Pelajar

Syaiful, Sagala. 2011. Konsep dan Makna Pembelajaran Untuk Membantu Memecahkan Problematika Belajar dan Mengajar. Bandung: Alfabeta.

Trianto. 2011. Model pembelajaran terpadu konsep, strategi dan implementasinya dalam Kurikulum Tinkat Satuan Pendidikan (KTSP). Jakarta: Bumi Aksara.

Windiarti. 2014. Perbedaan Kemampuan Penalaran Adaptif Siswa yang Diajar Menggunakan Model Pembelajaran Learning Cycle 7 e Dengan Model Pembelajaran Konvensional Pada Materi Luas Balok. Bandung: Alfabeta.

Zaini, Hisyam. 2010. Strategi Pembelajaran Aktif. Yogyakarta: Center for Teaching Staf Development (CTSD) UIN Sunan Kalijaga Yogyakarta. 